\title{
KEPEMIMPINAN PENDIDIKAN PESANTREN (Studi Kewibawaan Pada Pondok Pesantren Salafiyah, Modern, dan Kombinasi)
}

\author{
Nor Fithriah \\ Dosen, STIQ Amuntai, Kalimantan Selatan, Indonesia
}

\begin{abstract}
Abstrak
Pesantren merupakan salah satu jenis lembaga pendidikan Islam Indonesia yang bersifat tradisional untuk mendalami ilmu agama Islam dan mengamalkannya sebagai pedoman hidup keseharian. Pesantren telah diakui sebagai lembaga pendidikan yang telah ikut mencerdaskan kehidupan bangsa. Khazanah riwayat pesantren menggambarkan betapa kuat pengaruh kewibawaan kyai, mereka menjadi kiblat para pengikutnya. Kebijakan yang seringkali dituangkan secara lisan dijadikan pegangan, sikap dan tingkah lakunya sehari-hari dijadikan panutan, bahasa kiasan yang dilontarkannya acapkali menjadi bahan renungan, karena itu mekanisme administrasi pondok pesantren baik yang berkaitan dengan struktur organisasi kepemimpinan maupun arah perkembangan pesantren, tidak lepas dari peranan kyai. Dengan demikian, seringkali visi kyai merupakan barometer pondok pesantren. Penelitian ini merupakan penelitian lapangan (field research), yaitu penelitian yang dilakukan langsung di lokasi penelitian, yakni pada tiga Pondok Pesantren yang ada di Kalimantan Selatan yaitu Pondok Pesantren Nurul Muhibbin (Barabai), Pondok Pesantren Rasyidiyah Khalidiyah (Amuntai), dan Pondok Pesantren Al Falah (Banjarbaru).
\end{abstract}

Keywords : Kepemimpinan Pendidikan, Pesantren.

\section{A. Pendahuluan}

Pesantren merupakan salah satu jenis lembaga pendidikan Islam di Indonesia yang bersifat tradisional untuk mendalami ilmu agama dan mengamalkannya sebagai pedoman hidup sehari-hari. Pesantren telah diakui sebagai lembaga pendidikan yang telah ikut mencerdaskan kehidupan bangsa. Sejarah riwayat pesantren menggambarkan betapa kuat pengaruh seorang kyai/pimpinan pondok pesantren, karena itu mekanisme administrasi pondok pesantren baik yang berkaitan dengan struktur organisasi kepemimpinan maupun arah perkembangan pesantren, tidak lepas dari peranan kyai.

Jurnal Ilmiah Al QALAM, Vol. 12, No. 1, Januari-Juni 2018 
Nor Fithriah: Kepemimpinan Pendidikan Pesantren (Studi Kewibawaan pada Pondok Pesantren Salafiyah, Modern, dan Kombinasi)

Sebagai lembaga pendidikan tradisional umat Islam, pondok pesantren bertujuan mempelajari, memahami, mendalami, menghayati dan mengamalkan ajaran Islam dengan memberikan tekanan pada keseimbangan aspek perilaku (akhlak). Hal ini tentunya tergantung dengan model kepemimpinan seorang kyai yang diterapkan di sebuah pondok pesantren dalam merespon perubahan tersebut. Sebab secara umum, dari segi kepemimpinan pesantren masih terpola secara sentralistik, terpusat pada seorang kyai. Kyai sebagai salah satu unsur dominan dalam kehidupan sebuah pesantren, ia mengatur irama pekembangan dan keberlangsungan kehidupan suatu pesantren dengan keahlian, kedalaman ilmu, karismatik, dan keterampilannya. Sehingga tidak jarang sebuah pesantren tanpa memiliki manajemen pendidikan yang rapi, sebab segala sesuatu terletak pada kebijaksanaan dan keputusan kyai. ${ }^{1}$

Khazanah riwayat pesantren menggambarkan betapa kuat pengaruh kewibawaan seorang kyai, mereka menjadi kiblat para pengikutnya. Kebijakan yang seringkali dibuat dijadikan pegangan, sikap dan tingkah laku kyai seharihari dijadikan panutan, bahasa kiasan yang dilontarkannya juga seringkali menjadi bahan renungan dan pembelajaran, dengan demikian, seringkali visi dan misi kyai merupakan barometer sebuah lembaga pondok pesantren.

Seorang kyai dalam budaya pesantren memiliki berbagai macam peran, termasuk sebagai ulama, pendidik dan pengasuh, penghubung masyarakat, pemimpin, dan pengelola pesantren. Peran yang begitu kompleks tersebut menuntut kyai untuk bisa memposisikan dirin dalam berbagai situasi yang dijalaninya. Sehingga dibutuhkan sosok kyai yang mempunyai kemampuan, dedikasi dan komitmen yang tinggi untuk bisa menjalankan peran-peran tersebut.

Berdasarkan beberapa peran tersebut, peran yang paling vital adalah dalam hal kepemimpinan. Hal ini tak lepas dari pentingnya kepemimpinan kyai itu sendiri dalam mengelola pesantren, karena di dalam

${ }^{1}$ Hasbullah, Sejarah Pendidikan Islam di Indonesia, (Jakarta, PT. Raja Grafindo Persada,2001), h. 49

Jurnal Ilmiah Al QALAM, Vol. 12, No. 1, Januari-Juni 2018 
Nor Fithriah: Kepemimpinan Pendidikan Pesantren (Studi Kewibawaan pada Pondok Pesantren Salafiyah, Modern, dan Kombinasi)

pesantren kyai merupakan tokoh kunci yang sangat menentukan berhasil tidaknya pendidikan yang ada di pesantren. Selain itu, ia juga merupakan uswatun hasanah, representasi serta idola masyarakat sekitarnya.

Fenomena tersebut di atas banyak sekali terjadi di dunia pesantren, begitu juga di berbagai pondok pesantren yang ada di Kalimantan Selatan, yang dari sekian banyak pesantren tersebut memiliki ciri atau corak yang berbeda. Pertama, yang bercorak salafiyah, yaitu pesantren yang masih memegang tradisi ke-salafiyah-annya, yang dalam pelaksanaannya sorang ulama atau kyai memegang peran 'klasik' sebagai sumber ilmu, pendidik, dan pengasuh sebuah pesantren. Kedua, pesantren yang bercorak modern, yaitu kebalikan dari pesantren salafiyah, pesantren modern menerima arus modernisme, baik pemikiran, model maupun referensinya. Ketiga, pesantren yang bercorak kombinasi atau perpaduan salaf dan modern, yaitu pesantren yang menerima sebagian modernisme kemudian dipadu dengan tradisi pesantren klasik/salafiyah. Dari sekian banyak pondok pesantren di Kalimantan Selatan, ada tiga pondok pesantren yang dianggap mewakili masing-masing tipe/corak. Pondok Pesantren Nurul Muhibbin Barabai yang bercorak salafiyah, Pondok Pesantren Rasyidiyah Khalidiyah Amuntai yang bercorak modern, dan Pondok Pesantren Al Falah Banjarbaru yang bercorak kombinasi salafiyah-modern.

\section{B. Kajian Teori}

\section{Pengertian Kepemimpinan}

Kepemimpinan merupakan sebuah fenomena universal. Siapa pun menjalankan tugas-tugas kepemimpinan, manakala dalam tugas itu dia berinteraksi dengan orang lain. Kepemimpinan adalah sekumpulan dari serangkaian kemampuan dan sifat-sifat kepribadian, termasuk di dalamnya wibawa, untuk dijadikan sebagai sarana dalam rangka meyakinkan yang dipimpinnya agar mereka mau dan dapat melaksanakan tugas-tugas yang dibebankan kepadanya dengan rela, penuh semangat, ada kegembiraan 
Nor Fithriah: Kepemimpinan Pendidikan Pesantren (Studi Kewibawaan pada Pondok Pesantren Salafiyah, Modern, dan Kombinasi)

batin, serta merasa tidak terpaksa. ${ }^{2}$ Bahkan dalam kapasitas pribadi pun, di dalam tubuh manusia itu ada kapasitas atau potensi pengendali, yang pada intinya memfasilitasi seseorang untuk dapat memimpin dirinya sendiri.

Kepemimpinan merupakan sebuah fenomena yang kompleks, maka amat sukar untuk membuat rumusan yang menyeluruh tentang arti kepemimpinan. Oleh karenanya, tidak ada satu defenisi kepemimpinan pun dapat dirumuskan secara sangat lengkap untuk mengabstrakkan perilaku sosial atau perilaku interaktif manusia di dalam oranisasi yang memiliki regulasi dan struktur tertentu, serta misi yang kompleks.

Pengertian kepemimpinan dapat pula dikemukakan sebagai berikut ${ }^{3}$ :

a. Menurut Wahjosumidjo adalah suatu yang melekat pada diri seorang pemimpin yang berupa sifat-sifat tertentu seperti: kepribadian (personality), kemampuan (ability), dan kesanggupan (capability), kepemimpinan sebagai rangkaian kegiatan (activity) pemimpin yang tidak dapat dipisahkan dengan kedudukan (posisi) serta gaya atau perilaku pemimpin itu sendiri. Kepemimpinan adalah proses antarhubungan atau interaksi antara pemimpin, pengikut dan situasi.

b. Menurut Sutarto, pengertian kepemimpinan adalah rangkaian kegiatan penataan berupa kemampuan mempengaruhi perilaku orang lain adalah situasi tertentu agar bersedia bekerja sama untuk mencapai tujuan yang telah ditetapkan.

c. Pengertian kepemimpinan menurut S.P.Siagian adalah kemampuan dan keterampilan seseorang untuk menduduki jabatan sebagai pimpinan dalam suatu pekerjaan untuk mempengaruhi perilaku orang lain, terutama bawahannya supaya berpikir dan bertindak sedemikian rupa sehingga

\footnotetext{
${ }^{2}$ Ngalim Purwanto, Administrasi dan Supervisi Pendidikan", Cet XVI (Bandung: PT. Remaja Rosda Karya, 2006), hlm 26.

${ }^{3}$ http://www.artikelsiana.com/2015/08/pengertian-kepemimpinan-fungsisejarah.html(diakses tanggal 22 September 2015)
}

Jurnal Ilmiah Al QALAM, Vol. 12, No. 1, Januari-Juni 2018 
Nor Fithriah: Kepemimpinan Pendidikan Pesantren (Studi Kewibawaan pada Pondok Pesantren Salafiyah, Modern, dan Kombinasi)

melalui perilaku positif ini memberikan sumbangna nyata dalam pencapaian tujuan organisasi.

d. Pengertian kepemimpinan dimana menurut Moejiono bahwa kepemimpinan adalah sebagai akibat penagaruh satu arah, karena pemimpin mungkin memiliki kualitas-kualitas tertentu yang membedakan dirinya dengan pengikutnya.

e. D. E. Mc. Farland mengemukakan bahwa kepemimpinan adalah suatu proses dimana pimpinan dilukiskan akan member perintah atau pengaruh, bimbingan atau proses mempengaruhi pekerjaan orang lain dalam memilih dan mencapai tujuan yang telah ditetapkan.

f. J. M. Pfiffner mengemukakan bahwa kepemimpinan adalah seni mengkoordinasi dan memberi arah kepada individu atau kelompok untuk mencapai tujuan yang diinginkan.

g. Oteng Sutisna mengemukakan bahwa kepemimpinan adalah kemampuan mengambil inisiatif dalam situasi sosial untuk menciptakan bentuk dan prosedur baru, merancang dan mengatur perbuatan, dan dengan berbuat begitu membangkitkan kerja sama ke arah tercapainya tujuan.

\section{Kepemimpinan Pendidikan Pesantren}

Dalam bangunan masyarakat Islami, pemimpin berada pada posisi yang menentukan terhadap perjalanan ummatnya. Apabila sebuah jamaah memiliki seorang pemimpin yang prima, produktif dan cakap dalam pengembangan dan kreatifitas amaliyah, maka dapat dipastikan perjalanan umatnya akan mencapai titik keberhasilan. Sebaliknya, manakala suatu jamaah dipimpin oleh orang yang memiliki banyak kelemahan, baik dalam hal keilmuan, manajerial, maupun dalam hal pemahaman dan nilai tanggung jawab, serta lebih mengutamakan hawa nafsunya dalam pengambilan keputusan dan tindakan, maka dapat dipastikan bangunan jamaah akan mengalami kemunduran, dan bahkan mengalami kehancuran. Oleh karena itu, Islam memandang bahwa kepemimpinan memiliki posisi yang sangat strategis dalam terwujudnya masyarakat yang berada dalam

Jurnal Ilmiah Al QALAM, Vol. 12, No. 1, Januari-Juni 2018 
Nor Fithriah: Kepemimpinan Pendidikan Pesantren (Studi Kewibawaan pada Pondok Pesantren Salafiyah, Modern, dan Kombinasi)

Baldatun Thoyyibatun Wa Rabbun Ghafûr (QS 34: 15), yaitu masyarakat yang dalam system kehidupannya menerapkan prinsip - prinsip Islam.

Istilah kepemimpinan apabila dikaitkan dengan organisasi kedinasan pemerintah maka disebut pemimpin. Apabila dikaitkan dengan administrasi maka disebut administrator, dan sebutan kiai adalah pimpinan pondok pesantren, sekalipun tidak semua kiai memimpin pondok pesantren. ${ }^{4}$

Pengertian umum pendidikan menurut ki Hajar Dewantara, berarti daya upaya untuk memajukan budi pekerti ( karakter, kekuatan bathin), pikiran (intellect) dan jasmani anak-anak selaras dengan alam dan masyarakatnya. ${ }^{5}$ Pendidikan ialah mengandung nilai yang meningkatkan kesejahteraan hidup manusia, yang mendorong manusia berusaha keras untuk meraih kehidupan yang membahagiakan.

Jadi definisi kepemimpinan pendidikan sebagai "satu kemampuan dan proses mempengaruhi, membimbing, mengkoordinir dan menggerakkan orang-orang lain yang ada hubungan dengan pengembangan ilmu pendidikan dan pelaksanaan pendidikan dan pengajaran, agar supaya kegiatan-kegiatan yang dijalankan dapat lebih efisien dan efektif di dalam pencapaian tujuan-tujuan pendidikan dan pengajaran."

Pada prinsipnya, setiap pengelolaan suatu lembaga pendidikan mensyaratkan adanya tipe pemimpin dan kepemimpinan yang khas. Misalnya, dalam era reformasi sekarang ini dibutuhkan kepemimpinan yang mampu memberdayakan masyarakat pesantren dengan tanpa mengorbankan ciri khas atau kredibilitas pengasuh pesantren. Dalam pesantren, kepemimpinan dilaksanakan di dalam kelompok kebijakan yang melibatkan sejumlah pihak, di dalam tim program, di dalam organisasi guru, orang tua dan murid (ustadz, wali santri, dan santri). Kepemimpinan

\footnotetext{
${ }^{4}$ Tesis A. Rafi'i, “Tipologi Kepemimpinan Kiai di Pondok Pesantren Al Falah Putri Banjarbaru", IAIN Antasari: Tesis, 2004, h. 25

${ }^{5}$ http://www.diwarta.com/2012/06/14/pengertian-pendidikan-menurut-kihajardewantara.html, diakses tanggal 22 September 2016
}

Jurnal Ilmiah Al QALAM, Vol. 12, No. 1, Januari-Juni 2018 
Nor Fithriah: Kepemimpinan Pendidikan Pesantren (Studi Kewibawaan pada Pondok Pesantren Salafiyah, Modern, dan Kombinasi)

yang membaur ini menjadi faktor pendukung aktifitas sehari-hari di lingkungan pondok pesantren.

Dari berbagai tingkatan konsistensi dengan sistem lama dan keterpengaruhan oleh sistem modern, secara garis besar pondok pesantren dapat dikategorikan ke dalam tiga bentuk, yaitu :

a. Pondok Pesantren Salafiyah

Salaf artinya "lama", "dahulu", atau "tradisional". Pondok pesantren salafiyah adalah pondok pesantren yang menyelenggarakan pembelajaran dengan pendekatan tradisional, sebagaimana yang berlangsung sejak awal pertumbuhannya. Pembelajaran agama Islam dilakukan secara individual atau kelompok dengan konsentrasi pada kitab-kitab klasik, berbahasa Arab.

b. Pondok Pesantren Khalafiyah ('Ashriyah)

Khalaf artinya "kemudian" atau "belakangan", sedangkan "ashri" artinya "sekarang" atau "modern". Pondok pesantren khalafiyah adalah pondok pesantren yang menyelenggarakan kegiatan pendidikan dengan pendekatan modern, melalui satuan pendidikan formal, baik madrasah (MI, MTs, MA atau MAK), maupun sekolah (SD, SMP, SMA dan SMK) atau nama lainnya.

c. Pondok Pesantren Campuran / Kombinasi

Pondok pesantren Campuran / Kombinasi menggabungkan dua sistem yang berbeda yaitu sistem salafiyah dan khalafiyah sekaligus sebagaimana penjelasan di atas. Sebagian besar yang ada sekarang adalah pondok pesantren yang berada di antara rentangan dua pengertian di atas. ${ }^{6}$

\section{Gaya dan Tipologi Kepemimpinan}

Berikut adalah beberapa gaya/tipe kepemimpinan, antara lain:

${ }^{6}$ Departemen Agama RI, Pondok Pesantren dan Madrasah Diniyah, (Jakarta : Direktorat Jenderal Kelembagaan Agama Islam, 2003), h. 1

Jurnal Ilmiah Al QALAM, Vol. 12, No. 1, Januari-Juni 2018 
Nor Fithriah: Kepemimpinan Pendidikan Pesantren (Studi Kewibawaan pada Pondok Pesantren Salafiyah, Modern, dan Kombinasi)

a. Tipe kepemimpinan kharismatik

Dalam kepemimpinan yang berwibawa memiliki energi, daya tarik dan pembawa yang luar biasa untuk mempengaruhi orang lain, sehingga ia mempunyai pengikut yang sangat besar jumlahnya dan pengawal pengawal yang bisa dipercaya. Sampai sekarang pun orang tidak mengetahui benar sebab-sebabnya mengapa seseorang itu memiliki Wibawa besar. Dia dianggap mempunyai kekuatan ghaib (supernaturalpower) dan kemampuan-kemampuan yang superhuman, yang diperolehnya sebagai karunia Yang Maha Kuasa. Dia banyak memiliki inspirasi, keberanian, dan berkeyakinan teguh pada pendirian sendiri. Totalitas kepribadian pemimpin itu memancarkan pengaruh dan daya tarik yang teramat besar.

b. Tipe kepemimpinan paternalistik

Yaitu tipe kepemimpinan kebapakan, dengan sifat-sifat antara lain sebagai berikut:

1) Menganggap bawahannya sebagai manusia yang tidak/belumdewasa, atau anak-anak sendiri yang perlu dikembangkan.

2) Bersikap terlalu melindungi.

3) Jarang memberikan kesempatan kepada bawahan untuk mengambilkeputusan sendiri.

4) Hampir-hampir tidak pernah memberikan kesempatan kepadabawahan untuk berinisiatif.

5) Tidak memberikan kesempatan kepada bawahan untukmengembangkan imajinasi dan kreativitasnya.

6) Selalu bersikap maha-tahu dan maha benar.

c. Tipe kepemimpinan otoriter

Kepemimpinan ini mendasarkan diri pada kekuasaan dan paksaan yang mutlak dan harus dipenuhi. Pemimpin selalu mau berperan sebagai pemain tunggal. Pada a one-man show, dia sangat 
Nor Fithriah: Kepemimpinan Pendidikan Pesantren (Studi Kewibawaan pada Pondok Pesantren Salafiyah, Modern, dan Kombinasi)

berambisi untuk merajai situasi. Setiap perintah dan kebijakan ditetapkan tanpa berkonsultasi dengan bawahannya. Anak buah tidak pernah diberi informasi mendetail mengenai rencana dan tindakan yang harus dilakukan. Semua pujian dan kritik terhadap segenap anak buah diberikan atas pertimbangan pribadi pemimpin sendiri. ${ }^{7}$ Dalam kepemimpinan yang otokratis, pemimpin bertindak sebagai diktator terhadap anggota-anggota kelompoknya. Baginya memimpin adalah menggerakkan dan memaksa kelompok. Penafsirannya sebagai pemimpin tidak lain adalah menunjukkan dan memberi perintah. Kewajiban anggota atau bawahan hanyalah mengikuti dan menjalankan tidak boleh membantah atapun mengajukan saran. Seorang pemimpin dapat dikategorikan pada tipe otokratik, antara lain:

1) Menganggap organisasi sebagai milik pribadi

2) Mengidentikkan tujuan pribadi dengan tujuan organisasi

3) Menganggap bawahan sebagai alat semata

4) Tidak mau menerima kritik, saran, dan pendapat

5) Terlalu bergantung kepada kekuasaan formalnya

6) Dalam tindakan penggerakannya sering mempergunakan approach yang mengandung unsur paksaan dan punitif (bersifat menghukum). ${ }^{8}$

d. Tipe kepemimpinan demokratis

Kepemimpinan demokratis berorientasi pada manusia, dan memberikan bimbingan yang efisien kepada para pengikutnya. Terdapat koordinasi pekerjaan pada semua bawahan, dengan penekanan pada rasa tanggung jawab internal (pada diri sendiri) dan

\footnotetext{
${ }^{7}$ Veithzal Rivai, Kepemimpinan dan Perilaku Organisasi, Jakarta PT. RajaGrafindo Persada 2007, h. 90

${ }^{8}$ Ngalim Purwanto, Administrasi dan Supervisi Pendidikan,Cet XVI (Bandung: PT.Remaja Rosda Karya, 2006), h 48.
}

Jurnal Ilmiah Al QALAM, Vol. 12, No. 1, Januari-Juni 2018 
Nor Fithriah: Kepemimpinan Pendidikan Pesantren (Studi Kewibawaan pada Pondok Pesantren Salafiyah, Modern, dan Kombinasi)

kerja sama yang baik. Kekuatan kepemimpinan demokratis ini bukan terletak pada "person atau individu pemimpin", tetapi kekuatan justru terletak pada partisipasi aktif dari setiap kelompok.

Kepemimpinan demokratis menghargai potensi setiap individu dan mendengarkan nasihat dan sugesti bawahan. Juga bersedia mengakui keahlian para spesialis dengan bidangnya masing-masing, mampu memanfaatkan kapasitas setiap anggota seefektif mungkin pada saat-saat dan kondisi yang tepat.

Kepemimpinan demokratis sering disebut sebagai kepemimpinan group developer. Pemimpin yang bertipe demokratis menafsirkan kepemimpinannya bukan sebagai diktator, melainkan sebagai pemimpin ditengah-tengah anggota kelompoknya. Pemimpin yang demokratis selalu berusah menstimulasi anggota-anggotanya agar bekerja secara kooperatif untuk mencapai tujuan bersama. Dalam tindakan dan usaha-usahanya, ia selalu berpangkal pada kepentingan dan kebutuhan kelompoknya, dan mempertimbangkan kesanggupan serta kemampuan kelompoknya.

Pemimpin yang demokratis dalam melaksanakan tugasnya, mau menerima dan bahkan mengharapkan pendapat dan saran-saran dari kelompoknya. Juga kritik-kritik yang membangun dari para anggota diterimanya sebagai umpan balik dan dijadikan bahan pertimbangan dalam tindakan-tindakan berikutnya. Ia juga mempunyai kepercayaan terhadap diri sendiri dan menaruh kepercayaan pula pada anggota-anggotanya bahwa mereka mempunyai kesanggupan bekerja dengan baik dan bertanggung jawab. Diantara sifat-sifat atau ciri-ciri pemimpin yang demokratis adalah:

1) Dalam proses penggerakan bawahan selalu bertitik tolak dari pendapat bahwa manusia itu adalah makhluk yang termulia di dunia

Jurnal Ilmiah Al QALAM, Vol. 12, No. 1, Januari-Juni 2018 
Nor Fithriah: Kepemimpinan Pendidikan Pesantren (Studi Kewibawaan pada Pondok Pesantren Salafiyah, Modern, dan Kombinasi)

2) Selalu berusaha mensinkronisasikan kepentingan dan tujuan organisasi dengan kepentingan dan tujuan pribadi para bawahannya

3) Ia senang menerima saran, pendapat, bahkan kritik dari bawahannya

4) Selalu berusaha mengutamakan kerja sama dan teamwork dalam usaha mencapai tujuan

5) Dengan ikhlas memberikan kebebasan seluas-luasnya kepada bawahannya untuk berani bertindak meskipun mungkin berakibat pada kesalahan yang kemudian dibimbing dan diperbaiki agar bawahan itu tidak lagi berbuat kesalahan yang sama, akan tetapi lebih berani untuk bertindak di masa depan

6) Selalu berusaha untuk menjadikan bawahannya lebih sukses dari padanya

7) Berusaha mengembangkan kapasitas diri pribadinya sebagai pemimpin.

e. Tipe kepemimpinan Laissez faire

Pada tipe kepemimpinan laissez faire ini sang pemimpin praktis tidak memimpin, dia membiarkan kelompoknya dan setiap orang berbuat semau sendiri. Pemimpin tidak berpartisipasi sedikit pun dalam kegiatan kelompokya. Semua pekerjaan dan tanggung jawab harus dilakukan oleh bawahan sendiri. Dia merupakan pemimpin simbol, dan biasanya tidak memiliki keterampilan teknis sebab duduknya sebagai direktur atau pemimpin-ketua dewan, komandan, atau kepala biasanya diperoleh melalui penyogokan, suapan atau sistem nepotisme. ${ }^{9}$

${ }^{9}$ Ara Hidayat, Imam Machali, Pengelolaan Pendidikan (Konsep, Prinsip dan Aplikasi dalam Mengelola Sekolah dan Madrasah), Bandung: Pustaka Educa, 2010, h. 85.

Jurnal Ilmiah Al QALAM, Vol. 12, No. 1, Januari-Juni 2018 
Nor Fithriah: Kepemimpinan Pendidikan Pesantren (Studi Kewibawaan pada Pondok Pesantren Salafiyah, Modern, dan Kombinasi)

Dalam tipe kepemimpinan ini sebenarnya pemimpin tidak memberikan pimpinan/pengarahan. Tipe ini diartikan sebagai membiarkan orangorang berbuat sekehendaknya. Pemimpin yang termasuk tipe ini sama sekali tidak memberikan kontrol dan koreksi terhadap pekerjaan anggota- anggotanya. Pembagian tugas dan kerja sama diserahkan kepada angota-anggota kelompok, tanpa petunjuk atau saran-saran dari pimpinan. Kekuasaan dan tanggung jawab bersimpang siur, berserakan diantara anggota-anggota kelompok, tidak merata.

Tingkat keberhasilan organisasi atau lembaga yang dipimpin dengan gaya laissez faire semata-mata disebabkan karena kesadaran dan dedikasi beberapa anggota kelompok, dan bukan karena pengaruh dari pimpinannya. Sifat kepemimpinan dalam tipe ini tidak tampak, anggota kelompok bekerja menurut kehendaknya masing-masing tanpa adanya pedoman kerja yang baik. Di sini seorang pemimpin mempunyai keyakinan bahwa dengan memberikan kebebasan yang seluas-luasnya terhadap bawahan, maka semua usahanya akan dapat berhasil.

\section{Pengertian Kewibawaan}

Dalam Kamus Besar Bahasa Indonesia, pengertian wibawa adalah pembawaan untuk dapat menguasai dan mempengaruhi dihormati orang lain melalui sikap dan tingkah laku yang mengandung kepemimpinan dan penuh daya tarik. ${ }^{10}$ Wibawa adalah keadaan atau bakat yang dihubungkan dengan kemampuan yang luar biasa dalam hal kepemimpinan seseorang untuk membangkitkan pemujaan dan rasa kagum dari masyarakat terhadap dirinya.

\footnotetext{
${ }^{10}$ http://kbbi.web.id/wibawa, Kamus Besar Bahasa Indonesia (KBBI), Kamus versi online/daring (dalam jaringan), diakses tanggal 15 April 2015.
}

Jurnal Ilmiah Al QALAM, Vol. 12, No. 1, Januari-Juni 2018 
Nor Fithriah: Kepemimpinan Pendidikan Pesantren (Studi Kewibawaan pada Pondok Pesantren Salafiyah, Modern, dan Kombinasi)

Untuk mampu memengaruhi dan menggerakkan sedemikian rupa, seorang pemimpin perlu memiliki sifat atau bakat. Kepemimpinan terjadi karena sifat-sifat atau bakat yang khas yang terdapat dalam diri pemimpin yang dapat diwujudkan dalam prilaku kepemimpinan. Sifat atau bakat itu dinamakan wibawa.

Dalam bahasa Inggris "authority"; power or talent given by God, authority; emphasizing the divine gifts. ${ }^{11}$ Kewibawaan adalah pemberian Tuhan. Kewibawaan adalah sifat seorang figur yang mempunyai wibawa dan merupakan pemberian Tuhan. Dalam bahasa Indonesia dijelaskan bahwa "wibawa" adalah keadaan atau bakat yang dihubungkan dengan kemampuan yang luar biasa dalam hal kepemimpinan seseorang untuk membangkitkan pemujaan atau rasa kagum dari masyarakat terhadap dirinya, atau kepemimpinan yang didasarkan atas kualitas kepribadian individu.

Kewibawaan adalah sifat seseorang yang mempunyai kualitas tertentu bagi seseorang individu yang menyebabkan dirinya berbeda dengan orang biasa dan diperlakukan sebagai orang yang mendapat karunia sifat adikodrati, adimanusiawi atau kekuatan dan kualitas yang sangat luar biasa. $^{12}$

Dalam menilai kemampuan penguasa dalam menjalankan tugasnya sebagai pemimpin bagi orang-orang yang dikuasainya dapat dilihat dari kewibawaannya. Seseorang dapat dinilai kewibawannya setelah dia memiliki kedudukan dalam kekuasaan. Oleh karena itu, Kepemimpinan seorang penguasa tidak terlepas dari penilaian masyarakat tentang wibawanya sebagai pemimpin.

\footnotetext{
${ }^{11}$ A.S. Hornby, Oxford Advanced Leaners Dictionary, (Oxford: Oxford University Press, 1989), h. 189.

${ }^{12}$ David L. Sills (ed.), International Encyclopedia of the Social Sciences, (New York: the Macmillan Company \& the Free Press, t. th), vol. 1 h. 386-387. Lihat Bryan Wilson, The Noble Savages The Primitive Origins of Charisma and its Contemporery Survival (Berkeley: University of California Press, 1975), h. 4.
}

Jurnal Ilmiah Al QALAM, Vol. 12, No. 1, Januari-Juni 2018 
Nor Fithriah: Kepemimpinan Pendidikan Pesantren (Studi Kewibawaan pada Pondok Pesantren Salafiyah, Modern, dan Kombinasi)

\section{Analisis}

Penelitian yang dilakukan adalah penelitian lapangan (field research), yaitu penelitian yang dilakukan langsung dilokasi penelitian, yakni pada tiga Pondok Pesantren yang ada di Kalimantan Selatan yaitu Pondok Pesantren Nurul Muhibbin (Barabai),Pondok Pesantren Rasyidiyah Khalidiyah (Amuntai), dan Pondok Pesantren Al Falah Puteri (Banjarbaru).Fokus penelitian ini adalah tentang kewibawaan pimpinan Pondok Pesantren di Kalimantan Selatan. Ini berarti sasaran kajian dalam penelitian ini adalah kewibawaan pimpinan pendidikan, dan gaya kepemimipinan pada Pondok Pesantren.

Pondok Pesantren Nurul Muhibbin Barabai merupakan pondok pesantren dengan corak salafiyah, yang dipimpin K.H. Muhammad Bakhiet bin K.H. Ahmad Mugnie bin K.H. Ismail. Beliau adalah orang yang disiplin, tegas, dan berilmu pengetahuan (alim), dan mempunyai ribuan pengikut yang memenuhi setiap pengajian beliau. Beliau adalah oang yang berwibawa dan kharismatik, yang muncul karena faktor kharismatik dan kepribadian, dan kewibawaan tersebut juga muncul dari sumber diantaranya: referent power, expert power, dan charismatic power:

Pondok pesantren Rasyidiyah Khalidiyah dipimpin oleh seorang ulama yakni KH. Husin Naparin Lc, MA. Beliau adalah orang yang sangat berwibawa. Jam terbang yang tinggi dalam berdakwah dan pembawaan diri yang santun membuat beliau disegani oleh rekan - rekan dan bawahannya.

Pondok Pesantren al-Falah Pondok dipimpin oleh KH. Nur Syahid. Beliau adalah tokoh yang berwibawa dan dihormati oleh orang-orang sekitarnya. Beliau dikenal sebagai ulama yang sederhana dan ikhlas dalam bertindak dan berbuat serta disegani para ustadz/ustadzah dan santri/santriwati juga masyarakat.

Gaya kepemimpinan yang digunakan oleh pimpinan ketiga pondok pesantren tersebut adalah:

Jurnal Ilmiah Al QALAM, Vol. 12, No. 1, Januari-Juni 2018 
Nor Fithriah: Kepemimpinan Pendidikan Pesantren (Studi Kewibawaan pada Pondok Pesantren Salafiyah, Modern, dan Kombinasi)

a. Pada pondok pesantren Nurul Muhibbin, KH. Muhammad Bakhiet menggunakan gaya kepemimpinan kharismatik dan demokratis, tapi gaya kharismatiklebih dominan, hal ini terlihat dalam memutuskan sesuatu yang berkaitan dengan pengelolaan pendidikan pondok pesantren. Tapi dalam pelaksanaan hariannya, KH. Muhammad Bakhiet menyerahkan atau memberikan kepercayaan kepada seorang ustadz untuk membantu beliau. Musyawarah bersama atau rapat juga ada dilakukan, seperti merumuskan tata tertib pondok pesantren, para ustadz memberikan rumusan-rumusan, dan yang keeputusan tetap diserahkan kepada pimpinan.

b. Pada pondok pesantren Rasyidiyah Khalidiyah, KH. Husin Naparin Lc, MA menggunakan gaya Laissez faire yang secara operasinalnya menggunakan fungsi konsultasi dan delegasi.Beliau rutin mengadakan kunjungan bulanan yang dilaksanakan pada malam hari di pondok pesantren Rasyidiyah Khalidyah, kemudian besok siangnya dilanjutkan dengan rapat dengan pengurus yayasan.

c. Pada pondok pesantren Al-Falah, KH. Nur Syahid menggunakan gaya kepemimpinan demokratis, hal ini terlihat dalam memutuskan sesuatu dengan musyawarah. Dalam pelaksanaannnya, al-Falah Putera dan Puteri masing-masing mempunyai pimpinan yakni Mudir dan Mudirah. Mudir/mudirah biasanya mendiskusikan keputusan-keputusan yang akan diambil kepada pimpinan yayasan.

\section{Penutup}

Kepemimpinan adalah suatu kegiatan dalam membimbing suatu kelompok sedemikian hingga atau rupa sehingga tercapai tujuan dari kelompok itu yaitu tujuan bersama. Pendidikan bersifat universal, berlaku dan terdapat pada kepemimpinan diberbagai bidang kegiatan atau hidup manusia. Dalam konsep Islam, pemimpin merupakan hal yang sangat vital dan fundamental. Ia menempati posisi tertinggi dalam bangunan masyarakat Islam. Dalam 
Nor Fithriah: Kepemimpinan Pendidikan Pesantren (Studi Kewibawaan pada Pondok Pesantren Salafiyah, Modern, dan Kombinasi)

kehidupan berjamaah, pimpinan ibarat kepala dari seluruh anggota tubuhnya. Ia memiliki peranan yang strategis dalam pengaturan pola (minhaj) dan gerakan (harakah). Kecakapannya dalam memimpin akan mengarahkan umatnya kepada tujuan yang ingin dicapai, yaitu kejayaan dan kesejahteraan ummat dengan iringan ridha Allah.

Dalam bangunan masyarakat Islami, pemimpin berada pada posisi yang menentukan terhadap perjalanan ummatnya. Apabila sebuah jamaah memiliki seorang pemimpin yang prima, produktif dan cakap dalam pengembangan dan kreatifitas amaliyah, maka dapat dipastikan perjalanan umatnya akan mencapai titik keberhasilan. Sebaliknya, manakala suatu jamaah dipimpin oleh orang yang memiliki banyak kelemahan, baik dalam hal keilmuan, manajerial, maupun dalam hal pemahaman dan nilai tanggung jawab, serta lebih mengutamakan hawa nafsunya dalam pengambilan keputusan dan tindakan, maka dapat dipastikan bangunan jamaah akan mengalami kemunduran, dan bahkan mengalami kehancuran. 
Nor Fithriah: Kepemimpinan Pendidikan Pesantren (Studi Kewibawaan pada Pondok Pesantren Salafiyah, Modern, dan Kombinasi)

\section{Daftar Pustaka}

Departemen Agama RI, Pondok Pesantren dan Madrasah Diniyah, Jakarta : Direktorat Jenderal Kelembagaan Agama Islam, 2003.

Hasbullah, Sejarah Pendidikan Islam di Indonesia,Jakarta: PT. Raja Grafindo Persada, 2001.

Hidayat, Ara,dan Machali, Imam, Pengelolaan Pendidikan (Konsep, Prinsip dan Aplikasi dalam Mengelola Sekolah dan Madrasah), Bandung: Pustaka Educa, 2010.

Kamus Besar Bahasa Indonesia (KBBI), Kamus versi online/daring (dalam jaringan), http://kbbi.web.id/wibawa.

Purwanto, Ngalim, Administrasi dan Supervisi Pendidikan, Cet XVI, Bandung: PT. Remaja Rosda Karya, 2006.

Rivai, Veithzal, Kepemimpinan dan PerilakuOrganisasi, Jakarta: PT. Raja GrafindoPersada 2007.

Yaqin, Husnul, Sistem Pendidikan Pesantren di Kalimantan Selatan, Banjarmasin: Antasari Press Banjarmasin, 2009.

Jurnal Ilmiah Al QALAM, Vol. 12, No. 1, Januari-Juni 2018 
Nor Fithriah: Kepemimpinan Pendidikan Pesantren (Studi Kewibawaan pada Pondok Pesantren Salafiyah, Modern, dan Kombinasi)

Jurnal Ilmiah Al QALAM, Vol. 12, No. 1, Januari-Juni 2018 